\title{
Quality of Coffea arabica seedlings produced in different nurseries in southern Minas Gerais, Brazil
}

Anderson Barreto dos Passos ${ }^{1}$

Bruno Manoel Rezende de Melo

Sindynara Ferreira ${ }^{3}$

Douglas Goulart Castro 4

Telma Miranda dos Santos 5

Leonardo Alves Guedes ${ }^{6}$

\section{Abstract}

Obtaining high-quality seedlings is a step of fundamental importance for the successful implementation of a coffee crop, which can be measured by evaluating seedling morphological and quality parameters. This study examines the quality of coffee seedlings produced in nurseries in the municipalities of Inconfidentes, Ouro Fino, and Jacutinga, southern Minas Gerais State, Brazil. The experiment was carried out in nurseries here termed $1,2,3,4,5,6,7$ and 8, from 05/28/2017 to 02/28/2018. The experiment was developed in an $8 \times 2$ factorial arrangement consisting of 8 seedling nurseries and 2 cultivars (Catuaí strains IAC 62 and 144) evaluated in 3 replicates containing 8 seedlings each. The following traits were evaluated: leaf area (LA), total dry matter (TDM), shoot: root ratio (S: R), plant height: stem diameter ratio (HDR), and Dickson quality index (DQI). Data were subjected to combined analysis and, after significant differences were detected $(p<0.05)$, the Scott-Knott test of means was applied. The management adopted in the nurseries influenced the development of the evaluated cultivars. Seedlings from nursery 5 , of both evaluated cultivars; and from nursery 8 , of cultivar IAC 144, exhibited a DQI above 0.2, indicating superior quality. Only nursery 5 showed seedlings of adequate quality for both cultivars. Regardless of their location, the other coffee-seedling nurseries still did not produce seedlings of satisfactory quality to be taken to the field.

Keywords: DQI. Catuaí. Nurseryperson. Combined analysis.

\section{Introduction}

Coffee is one of the most important agricultural commodities in Brazil, which produced an estimated 44,774.3 thousand bags of processed coffee in 2017 from a cultivated area of 2,208.9 thousand hectares, 345,200 ha of which are under formation (CONAB, 2017).

The significant renovation of the coffee land and the consequent adaptation to the current planting systems have raised the demand for seedlings. Because coffee is a perennial crop, all its phases must be planned, especially those directly linked to the establishment and formation of the

1 Instituto Federal de Educação, Ciência e Tecnologia do Sul de Minas(IFSULDEMINAS).Engenheiro agrônomo.andersonbarretodospassos@ gmail.com. Praça Tiradentes, 416 - Centro, Inconfidentes/MG, 37576-000. 
crop. Carvalho et al. (2007) stated that any mistake in the implementation stage will negatively affect the crop over the years.

Mistakes occurring during this period can seriously compromise the crop, resulting in low yield and reduced longevity. Thus, the use of vigorous coffee seedlings ensures a lower rate of seedling mortality in the field, thereby reducing expenses with the replanting operation and contributing to a faster initial plant growth (CARVALHO; GUIMARÃES; NOGUEIRA, 2008; ALVES; GUIMARÃES, 2010).

One of the requirements imposed by the coffee-seedling market is high seedling quality. Among the many factors related to seedling production, container volume, substrate, water availability (FONTENO; BILDERBACK, 1993) and seedling health are important parameters to be observed in the production of high-quality seedlings.

Therefore, to verify the quality of these seedlings, analyses must be undertaken to obtain information on which stages require improvement.

To determine seedling quality, root and shoot growth and stem diameter are measured and later used to calculate the Dickson quality index (DQI), which provides information on seedling development (DICKSON; LEAF; HOSNER, 1960). These evaluation parameters are directly related to the seedling production processes and the adopted management.

This information will allow the nurseryperson to determine the period to sell the seedlings as well as the best time to start the production process in the following year. Lack of knowledge of the ideal time for transferring the seedlings to the field can result in losses due to factors such as leaf area, plant height: stem diameter ratio, or root system inadequate for seedling development, which can delay or suppress its growth in the field and oftentimes even compromise its survival (MUNGUABE, 2012).

Coffee-seedling production has evolved considerably, but specific management protocols must still be adopted for each reality, since there is no established methodology for the production of coffee seedlings, with variations existing in terms of container size, type of substrate used, and cultivation treatments throughout the process. This lack of standardization results in the production of seedlings with different characteristics that may or may not have the adequate quality to go to the field. To date, few studies have investigated the quality of coffee seedlings in a given region. This project provide data that assist in decision-making aiming at improved seedling quality, which has a positive impact on the entire coffee production chain.

Given the above-described scenario, the present study proposes to examine the quality of coffee seedlings produced in nurseries in the municipalities of Inconfidentes, Ouro Fino, and Jacutinga, southern Minas Gerais State, Brazil.

\section{Material and methods}

The experiment was carried out in eight commercial nurseries, here termed nurseries 1, 2, 3, 4, 5, 6, 7 and 8, located in the municipalities of Inconfidentes, Ouro Fino and Jacutinga, southern Minas Gerais State, Brazil.

\section{Characterization of the municipalities}

The municipalities of Inconfidentes, Ouro Fino, and Jacutinga are located at average altitudes of $1,150 \mathrm{~m}, 909 \mathrm{~m}$, and $833.58 \mathrm{~m}$, respectively. The climate is considered hot and temperate, of the Cwb type (subtropical/high-altitude tropical), according to Köppen and Geiger (1928), with average annual temperature ranging from $19.3^{\circ} \mathrm{C}$ to $19.5^{\circ} \mathrm{C}$. 
Maximum and minimum temperatures occur in the months of February and July, with respective averages of $21.6^{\circ} \mathrm{C}$ and $15.7^{\circ} \mathrm{C}$. Average annual precipitation ranges from $1,518 \mathrm{~mm}$ to $1,524 \mathrm{~mm}$, with most rainfall occurring from October to March (> $120 \mathrm{~mm}$ ) and the lowest volume from April to September ( $<80 \mathrm{~mm}$ ) (CLIMATE-DATA.ORG, 2018).

\section{Identification and demarcation of the sampled nurseries}

After the nurseries in each municipality were identified, data on production, seedling production methodology, and characterization of the nurseries were collected. Afterward, the experimental plots were demarcated at random for each cultivar within each replicate. This visit took place when the seedlings were still at the cotyledon leaf stage.

Subsequently, the nurseries continued to carry out the same management procedures as used in other coffee seedlings until they reached 180 days of sowing.

\section{Seedling production methodology adopted in the nurseries}

Table 1 describes the main information regarding the evaluated traits and the management adopted in each nursery.

Table 1 - Seedling production methodology adopted by nurseries 1, 2, 3, and 4, Minas Gerais, Brazil.

\begin{tabular}{|c|c|c|c|c|}
\hline Production & Nursery 1 & Nursery 2 & Nursery 3 & Nursery 4 \\
\hline $\begin{array}{l}\text { Production } \\
\text { container }\end{array}$ & $\begin{array}{l}18 \mathrm{~cm} \times 10 \mathrm{~cm} \\
\text { bags }\end{array}$ & $\begin{array}{l}18 \mathrm{~cm} \times 10 \mathrm{~cm} \\
\text { bags }\end{array}$ & $\begin{array}{l}18 \mathrm{~cm} \times 10 \mathrm{~cm} \\
\text { bags }\end{array}$ & $\begin{array}{l}18 \mathrm{~cm} \times 10 \mathrm{~cm} \\
\text { bags }\end{array}$ \\
\hline Sowing depth & $2 \mathrm{~cm}$ & $2 \mathrm{~cm}$ & $1 \mathrm{~cm}$ & $2 \mathrm{~cm}$ \\
\hline Bed cover & Dry grass & Dry grass & Dry grass & Dry grass \\
\hline Shade cloth & $50 \%$ & $50 \%$ & $50 \%$ & $50 \%$ \\
\hline Substrate & $\begin{array}{l}240 \mathrm{dm}^{3} \text { soil and } \\
60 \mathrm{~L}_{\text {chicken manure }}\end{array}$ & $\begin{array}{l}300 \mathrm{dm}^{3} \text { soil and } \\
60 \mathrm{~L} \mathrm{chicken} \mathrm{litter}^{2}\end{array}$ & $\begin{array}{l}180 \mathrm{dm}^{3} \text { soil and } \\
60 \mathrm{~L} \mathrm{chicken} \mathrm{litter}^{-}\end{array}$ & $\begin{array}{l}240 \mathrm{dm}^{3} \text { soil and } \\
60 \mathrm{~L} \text { cattle manure }\end{array}$ \\
\hline Fertilization & $\begin{array}{l}200 \mathrm{~g} \mathrm{KCl} \text { and } \\
750 \mathrm{~g} \mathrm{~S} . \mathrm{S} \text {. }\end{array}$ & $\begin{array}{l}1.5 \mathrm{~kg} \text { S.S. } \\
\text { for each } 90 \mathrm{dm}^{3}\end{array}$ & $\begin{array}{l}1 \mathrm{~kg} \mathrm{S.S.} \\
\text { for each } 240 \mathrm{dm}^{3}\end{array}$ & $\begin{array}{l}3.5 \mathrm{~kg} \mathrm{S.S.} \mathrm{for} \\
300 \mathrm{dm}^{3} \text { substrate }\end{array}$ \\
\hline Liming & Not applied & $250 \mathrm{~g} / \mathrm{m}^{2}$ of bed & Not applied & Not applied \\
\hline $\begin{array}{l}\text { Post-planting } \\
\text { fertilization }\end{array}$ & $\begin{array}{l}\text { Stimulate }^{\circledR} \text { applied } \\
40 \text { days after } \\
\text { germination and } \\
\text { fortnightly until the } \\
\text { penultimate month. }\end{array}$ & $\begin{array}{l}\text { Krista }^{\mathrm{TM}} \text { MAP applied } \\
\text { on the first pair of } \\
\text { leaves and } 15 \text { days } \\
\text { after } 1 \text { st application }\end{array}$ & Not applied & $\begin{array}{l}100 \text { g urea in } 50 \mathrm{~L} \\
\text { water after the first } \\
\text { pair of leaves and } \\
\text { another dose after } \\
15 \text { days }\end{array}$ \\
\hline Pesticides used & $\begin{array}{l}\text { Kasumin CS } \\
\text { Manzate } 800(\mathrm{WP})\end{array}$ & $\begin{array}{l}\text { Karate } 50 \text { EC } \\
\text { Dhitane WP }\end{array}$ & $\begin{array}{l}\text { Recop WP } \\
\text { Dithane WP } \\
\text { Monceren PM }\end{array}$ & $\begin{array}{l}\text { Dithane WP } \\
\text { Kasumin SL } \\
\text { Karate zeon } 50 \text { CS }\end{array}$ \\
\hline Irrigation & Sprinkler & Hose & Hose & Hose \\
\hline Weeding & By hand & By hand & By hand & By hand \\
\hline Acclimatization & 5 months & 4 pairs of leaves & $\begin{array}{l}\text { White shade net at } 5 \\
\text { months }\end{array}$ & Not done \\
\hline $\begin{array}{l}\text { Production } \\
\text { container }\end{array}$ & $\begin{array}{l}\text { Bag } \\
11 \mathrm{~cm} \times 22 \mathrm{~cm}\end{array}$ & $\begin{array}{l}18 \mathrm{~cm} \times 10 \mathrm{~cm} \\
\text { bags }\end{array}$ & $\begin{array}{l}18 \mathrm{~cm} \times 10 \mathrm{~cm} \\
\text { bags }\end{array}$ & $\begin{array}{l}18 \mathrm{~cm} \times 10 \mathrm{~cm} \\
\text { bags }\end{array}$ \\
\hline Sowing depth & $1 \mathrm{~cm}$ & $2 \mathrm{~cm}$ & $2 \mathrm{~cm}$ & $2 \mathrm{~cm}$ \\
\hline Bed cover & Dry grass & Dry grass & Dry grass & Dry grass \\
\hline Shade cloth & $30 \%$ & $55 \%$ & $50 \%$ & $50 \%$ \\
\hline
\end{tabular}


Table 1 - Continuation.

\begin{tabular}{|c|c|c|c|c|}
\hline Production & Nursery 1 & Nursery 2 & Nursery 3 & Nursery 4 \\
\hline Substrate & $\begin{array}{l}180 \mathrm{dm}^{3} \text { soil and } 60 \\
\text { L poultry litter }\end{array}$ & $\begin{array}{l}240 \mathrm{dm}^{3} \text { soil and } \\
60 \mathrm{~L} \text { poultry litter }\end{array}$ & $\begin{array}{l}180 \mathrm{dm}^{3} \text { soil and } 60 \\
L \text { poultry litter }\end{array}$ & $\begin{array}{l}240 \mathrm{dm}^{3} \text { soil and } 60 \\
\text { L poultry manure }\end{array}$ \\
\hline Fertilizer & $\begin{array}{l}5 \mathrm{~kg} \mathrm{~S} . \mathrm{S} \text { and } 1 \mathrm{~kg} \\
\mathrm{KCl} \text { per } \mathrm{m}^{3} \text { substrate }\end{array}$ & $\begin{array}{l}1.2 \mathrm{~kg} \text { S.S for } 300 \\
\mathrm{dm}^{3} \text { substrate }\end{array}$ & $\begin{array}{l}1 \mathrm{~kg} \text { S.S for } 240 \\
\mathrm{dm}^{3} \text { substrate }\end{array}$ & $\begin{array}{l}200 \mathrm{~g} \mathrm{KCl} \text { and } 750 \\
\text { g S.S for } 300 \mathrm{dm}^{3} \\
\text { substrate }\end{array}$ \\
\hline Liming & Not applied & $\begin{array}{l}300 \mathrm{~kg} \text { for } 500000 \\
\text { seedlings (surface) }\end{array}$ & $250 \mathrm{~g}$ por $\mathrm{m}^{2}$ of bed & Not applied \\
\hline $\begin{array}{l}\text { Post-planting } \\
\text { fertilization }\end{array}$ & Foliar, amino acid & Not applied & Not applied & $\begin{array}{l}\text { Stimulate, used } \\
40 \text { days after } \\
\text { germination and } \\
\text { fortnightly until the } \\
\text { penultimate month }\end{array}$ \\
\hline Pesticides used & $\begin{array}{l}\text { Kasumin SL } \\
\text { Dithane WP }\end{array}$ & $\begin{array}{l}\text { Dithane WP } \\
\text { Kasumin SL } \\
\text { Monceren PM }\end{array}$ & $\begin{array}{l}\text { Dithane WP } \\
\text { Karate Zeon } 50 \text { SC } \\
\text { Monceren PM }\end{array}$ & $\begin{array}{l}\text { Kasumin SL } \\
\text { Manzate } 80 \text { (WP) }\end{array}$ \\
\hline Irrigation & Sprinkler & Sprinkler & Hose & Sprinkler \\
\hline Weeding & $\begin{array}{l}\text { Goal BR herbicide; } \\
\text { by hand }\end{array}$ & By hand & By hand & By hand \\
\hline Acclimatization & $\begin{array}{l}\text { Reduced irrigation; } \\
\text { removal of shade } \\
\text { cloth at } 4 \text { to } 5 \\
\text { months }\end{array}$ & $\begin{array}{l}\text { White cloth } 93 \% \text {, } \\
2 \text { months before } \\
\text { planting }\end{array}$ & $\begin{array}{l}\text { Removal of shade } \\
\text { cloth }\end{array}$ & $\begin{array}{l}\text { Removal of shade } \\
\text { cloth at } 4.5 \text { months }\end{array}$ \\
\hline
\end{tabular}

Source: Elaborated by the authors (2018).

\section{Seedling evaluation}

Seedlings of coffee (Coffea arabica L.) cultivar Catuaí lines IAC 62 and IAC 144 were used in all nurseries, where they were evaluated at 180 days after sowing (DAS). In each nursery, sowing was carried out at a certain time of the year (TABLE 2).

Table 2 - Sowing dates of each cultivar in the respective nurseries. IFSULDEMINAS - Inconfidentes Campus. Inconfidentes/MG, 2018.

\begin{tabular}{ccccccccc}
\hline \multirow{2}{*}{ Cultivar } & \multicolumn{8}{c}{ Nursery } \\
\cline { 2 - 9 } & $\mathbf{1}$ & $\mathbf{2}$ & $\mathbf{3}$ & $\mathbf{4}$ & $\mathbf{5}$ & $\mathbf{6}$ & $\mathbf{7}$ & $\mathbf{8}$ \\
\hline IAC 62 & $05 / 30 / 17$ & $05 / 28 / 17$ & $05 / 28 / 17$ & $07 / 05 / 17$ & $08 / 28 / 17$ & $07 / 10 / 17$ & $06 / 12 / 17$ & $06 / 28 / 17$ \\
IAC 144 & $05 / 30 / 17$ & $05 / 28 / 17$ & $05 / 28 / 17$ & $07 / 05 / 17$ & $07 / 15 / 17$ & $06 / 15 / 17$ & $06 / 12 / 17$ & $07 / 30 / 17$ \\
\hline
\end{tabular}

Source: Elaborated by the authors (2018).

\section{Evaluated traits}

The following seedling quality traits were evaluated:

a) Leaf area (LA): determined by the method of Barros et al. (1973), using the following equation: $L A=0.667 \times L \times W$, at which $L A=$ estimate of leaf area $\left(\mathrm{cm}^{2}\right) ; C=$ longest leaf length (cm); $L=$ largest leaf width $(\mathrm{cm})$; 
b) Total dry matter (TDM): obtained by adding shoot dry matter (SDM) and root dry matter (RDM), with results expressed in grams.

c) Shoot: root ratio (S: R): the result of SDM divided by RDM;

d) Plant height: stem diameter ratio (HDR): the result of plant height $(\mathrm{PH})$ divided by stem diameter (SD);

e) Dickson quality index (DQI): obtained using shoot height, stem diameter, shoot dry matter and root dry matter data, by the following formula: $D Q I=[T D M /(H D R+S: R)]$; and

f) Genotype $\times$ environment interaction: this parameter was evaluated based on DQI data.

\section{Experimental design and statistical analysis}

The study was developed in an $8 \times 2$ factorial arrangement represented by 8 seedling nurseries and 2 cultivars, which were evaluated in 3 replicates with 8 seedlings each. Data were subjected to combined analysis and after significant differences were detected $(p<0.05)$, the Scott-Knott test of means (1974) was applied. The analyses were performed using Sisvar 4.6 software (FERREIRA, 2011).

\section{Results and discussion}

The summary of the analysis of variance of the study of the cultivar $\times$ nursery interaction for LA, TDM, S: R, HDR, and DQI is described in Table 3. All interactions were significant, indicating that management and environment influence these parameters, except $\mathrm{S}$ : R.

Table 3 - Summary of combined analysis of variance for leaf area (LA), total dry matter (TDM), shoot: root ratio (S: R), plant height: stem diameter ratio (HDR), and Dickson quality index (DQI) at 180 days after sowing. IFSULDEMINAS, Inconfidentes/MG, 2018.

\begin{tabular}{lcccccc}
\hline \multirow{2}{*}{ SV } & \multirow{2}{*}{ DF } & \multicolumn{7}{c}{ MS } \\
\cline { 3 - 7 } & & LA & TDM & S:R & HDR & DQI \\
\hline Cultivar (C) & 1 & $30570.68^{\text {ns }}$ & $0.06235^{*}$ & $2.8714^{\text {ns }}$ & $0.1271^{\text {ns }}$ & $0.000075^{\text {ns }}$ \\
Nursery (N) & 7 & $3640867.7297^{*}$ & $3.2500^{*}$ & $14.2944^{*}$ & $5.3197^{*}$ & $0.045742^{*}$ \\
$\mathrm{C} \times \mathrm{N}$ & 7 & $297790.19^{*}$ & $0.1998^{*}$ & $2.3671^{\mathrm{ns}}$ & $0.8151^{*}$ & $0.002151^{*}$ \\
Replicate (nurseries) & 16 & $25813.11^{\mathrm{ns}}$ & $0.0227^{*}$ & $0.8499^{\mathrm{ns}}$ & $0.05499^{\mathrm{ns}}$ & $0.000713^{*}$ \\
Residual & 16 & 18223.78 & 0.0086 & 1.1325 & 0.0473 & 0.000217 \\
Overall mean & & 931.17 & 1.03312 & 4.4429 & 4.1747 & 0.1245 \\
CV\% & & 14.50 & 9.01 & 23.95 & 5.21 & 11.82 \\
\hline
\end{tabular}

Source: Elaborated by the authors (2018).

\section{Leaf area}

Nursery 5 showed the highest LA mean for both cultivars. This trait is related to TDM, whose highest means were also obtained in nursery 5. The lowest LA means of cultivar IAC 144 were obtained in nurseries 2, 4, and 7; and for cultivar IAC 62, in nurseries 1, 2, 3, 4, and 7 (TABLE 4).

In the evaluation between the cultivars in the different environments, management and the environment were found to influence LA, since cultivar IAC 62 obtained better results in nurseries 2 , 4, 5, and 6. For cultivar IAC 144, the highest values were found in the other nurseries (TABLE 4).

The evaluation of leaf area is relevant, as it is through the leaves that the seedling captures solar energy, fixes $\mathrm{CO}_{2}$, and consequently performs photosynthesis, ensuring better growth. However, excessive leaf expansion can also be an indicator of compensation due to lower luminosity (DARDENGO et al. , 2013). 


\section{Total dry matter}

Nursery 5 showed the highest TDM means for both evaluated cultivars. In nurseries 1, 2, 3, 4, and 7, the lowest values were found for cultivar IAC 62; and in nursery 7, the least significant result was found for cultivar IAC 144 (TABLE 4).

The cultivars were influenced by the environment and management, considering that the highest TDM values were shown by nurseries 1, 2, 3, and 8 in cultivar IAC 144 and nurseries 5 and 6 in cultivar IAC 62.

Marana et al. (2008) considered TDM between $1.0 \mathrm{~g}$ to $1.8 \mathrm{~g}$ as reasonable for seedlings produced in tubes. In the present study, lower values were found in nurseries $1,2,3$, 4, and 7 for both cultivars. The other nurseries exhibited values within the recommended range or higher. Lemos et al. (2015) worked with citric acid and phosphorus doses in a standard substrate, using $22 \mathrm{~cm} \times$ $11 \mathrm{~cm}$ polyethylene bags, and obtained $3.15 \mathrm{~g}$ of dry matter using the adequate dose of these inputs, which agrees with the results found in nursery 5 .

Meneghelli et al. (2017) found total dry matter values ranging from 2.06 to $2.23 \mathrm{~g}$. Based on the literature descriptions, the results found in the present study for nursery 5 demonstrate that dry matter values higher than $2.06 \mathrm{~g}$ in seedlings produced in bags are more adequate for the quality of coffee seedlings produced in polyethylene bags.

Gomes and Paiva (2004) reported that TDM is a good indication of how resilient a seedling will be in the field. Its accumulation, as well as how it is distributed, is fundamental for the evaluation of the potential of a seedling during its cycle. 
Table 4 - Quality and growth traits of coffee seedlings: leaf area (LA), total dry matter (TDM), shoot: root ratio $(S: R)$, plant height: stem diameter ratio (HDR), and Dickson quality index (DQI), according to the evaluated cultivars and nurseries. IFSULDEMINAS - Inconfidentes Campus. Inconfidentes/MG, 2018.

\begin{tabular}{|c|c|c|c|c|c|c|c|c|}
\hline \multirow{2}{*}{ Cultivar } & \multicolumn{8}{|c|}{ Nursery } \\
\hline & 1 & 2 & 3 & 4 & 5 & 6 & 7 & 8 \\
\hline \multicolumn{9}{|c|}{ LA } \\
\hline IAC62 & $484.48 \mathrm{aA}$ & $382.41 \mathrm{aA}$ & $587.12 \mathrm{aA}$ & $383.12 \mathrm{aA}$ & $2809.83 b D$ & $1857.74 \mathrm{bC}$ & $265.96 a A$ & $880.63 a \mathrm{~B}$ \\
\hline IAC144 & $709.54 a B$ & $366.01 \mathrm{aA}$ & $848.03 \mathrm{bB}$ & $367.12 \mathrm{aA}$ & $2416.56 \mathrm{aD}$ & $894.33 a \mathrm{~B}$ & $311.18 \mathrm{aA}$ & $1334.45 b \mathrm{~b}$ \\
\hline \multicolumn{9}{|c|}{$\begin{array}{cc}\text { TDM } \\
\end{array}$} \\
\hline IAC62 & $0.58 a A$ & $0.53 a A$ & $0.67 a A$ & $0.44 \mathrm{aA}$ & $2.87 \mathrm{bD}$ & $1.75 \mathrm{bC}$ & $0.45 a A$ & $1.23 \mathrm{aB}$ \\
\hline IAC144 & $0.75 b c$ & $0.57 \mathrm{bB}$ & $0.97 \mathrm{bD}$ & $0.48 \mathrm{aB}$ & $2.25 \mathrm{aG}$ & $1.14 \mathrm{aE}$ & $0.29 \mathrm{aA}$ & $1.49 \mathrm{bF}$ \\
\hline \multicolumn{9}{|c|}{ S:R } \\
\hline IAC62 & $4.52 \mathrm{aA}$ & $4.31 \mathrm{aA}$ & $4.57 a A$ & $8.03 a B$ & $2.92 \mathrm{aA}$ & $4.39 \mathrm{aA}$ & $6.09 \mathrm{aA}$ & $2.64 \mathrm{aA}$ \\
\hline IAC144 & $4.34 \mathrm{aA}$ & $4.06 \mathrm{aA}$ & $3.81 \mathrm{aA}$ & $5.35 \mathrm{aB}$ & $2.91 \mathrm{aA}$ & $2.66 \mathrm{aA}$ & $7.51 \mathrm{aC}$ & $2.93 \mathrm{aA}$ \\
\hline \multicolumn{9}{|c|}{ HDR } \\
\hline IAC62 & $3.51 \mathrm{aB}$ & $2.93 a A$ & $3.67 a \mathrm{~B}$ & $3.87 \mathrm{aC}$ & $5.61 \mathrm{aE}$ & $6.29 \mathrm{bF}$ & $3.43 a \mathrm{aB}$ & $4.48 \mathrm{aD}$ \\
\hline IAC144 & $3.81 \mathrm{aB}$ & $2.92 \mathrm{aA}$ & $3.84 a B$ & $3.68 \mathrm{aB}$ & $5.75 \mathrm{aD}$ & $4.43 \mathrm{aC}$ & $3.94 \mathrm{bB}$ & $4.58 \mathrm{aC}$ \\
\hline \multicolumn{9}{|c|}{ DQI } \\
\hline IAC62 & $0.07 a B$ & $0.07 a B$ & $0.08 \mathrm{aB}$ & $0.04 \mathrm{aA}$ & $0.33 b D$ & $0.16 \mathrm{aC}$ & $0.04 a A$ & $0.17 \mathrm{aC}$ \\
\hline IAC144 & $0.09 \mathrm{bc}$ & $0.08 \mathrm{aC}$ & $0.12 \mathrm{bD}$ & $0.05 a B$ & $0.26 a \mathrm{G}$ & $0.16 \mathrm{aE}$ & $0.02 \mathrm{aA}$ & $0.20 \mathrm{bF}$ \\
\hline
\end{tabular}

* Means followed by the same lowercase letter in the columns and upper case letter in the rows do not differ according to the Scott-Knott test (1974) at the $5 \%$ probability level.

Source: Elaborated by the authors (2018).

\section{Shoot: root ratio}

In the evaluation of $\mathrm{S}$ : $\mathrm{R}$, the highest mean was obtained by nursery 4 , in cultivar IAC 62 . The other nurseries showed no difference for this trait. For cultivar IAC 144, the highest S: R was obtained in nursery 7 (TABLE 4).

Marana et al. (2008) worked with seedlings in tubes and described ideal S: R values as between 4.7 and 7. For cultivar IAC 62, only nursery 7 agreed with the recommended range, and for cultivar IAC 144, only nursery 4 provided values within this range.

In the opinion of Kainuma et al. (2002), ideal S:R indices are between 4 and 7, with values above 7 indicating that the seedling had its shoots overly developed at the expense of the root, whereas values below 4 suggest that the seedling does not have a well-developed aerial part.

Despite the S: R of 2.92 and 2.29 shown by cultivars IAC 62 and 144 in nursery 5, which are below the values reported by Marana et al. (2008) and Kainuma et al. (2002), this nursery exhibited the highest values for $\mathrm{H}(22.22 \mathrm{~cm}$ and $20.91 \mathrm{~cm}), \mathrm{SD}(3.96 \mathrm{~mm}$ and $3.63 \mathrm{~mm}), \mathrm{SDM}(2.13 \mathrm{~g}$ and $1.67 \mathrm{~g})$ and RDM $(0.73 \mathrm{~g}$ and $0.58 \mathrm{~g})$ for both cultivars. When analyzed in isolation, these results are indicative of good-quality seedlings. These findings suggest that the $S: R$ value found in nursery 5 is more adequate for seedlings produced in polyethylene bags, and thus new S:R values should be considered for seedlings produced in this type of container.

Seedlings with higher S:R tend to have a disproportion between the shoots and the root system, thus being at greater odds of experiencing water stress induced by high transpiration and consequent inefficient water supply by the root system. Moraes et al. (2010) stated that coffee plants growing in full sun, with a high $S: R$, do not grow properly, since water supply to the shoots is not sufficient. 


\section{Plant height: stem diameter ratio}

Results for the HDR trait across the nurseries ranged from 2.93 to 6.29 (nurseries 2 and 6 , respectively) for cultivar IAC 62 and from 2.92 to 5.75 (nurseries 2 and 5, respectively) for cultivar IAC 144 (TABLE 4). Pereira, Lima and Melo Junior (2017) worked with different organic residues mixed with a commercial substrate and found maximum HDR values ranging from 4.64 to 6.9.

Marana et al. (2008) established HDR values that ranged from 3.5 to 4.0 as appropriate for seedlings in tubes, with higher values indicating excessive seedling growth and lower values indicating reduced growth.

Nurseries 1, 3, 4, and 7 showed HDR values that agreed with those recommended in the literature, for both evaluated cultivars. However, the plant heights obtained in these nurseries were the lowest, which influenced the HDR values. Therefore, these results do not indicate high-quality seedlings.

The HDR values that exceeded the range deemed adequate can be adjusted through changes in management, such as reduced irrigation and foliar fertilization. Very high values can also be due to excessive shading, which causes the seedlings to etiolate. Lower HDR values are also not indicative of quality, since the growth in height may have been lower than expected due to a lack of nitrogen or water.

\section{Dickson quality index}

The DQI is positively correlated with SDM and RDM (DARLENGO et al., 2013). In the present study, nursery 5 showed the best DQI for both cultivars, as well as the largest LA and total DM and the most adequate $S$ : R.

The DQI values found across the nurseries ranged from 0.04 to 0.33 for cultivar IAC 62 and from 0.26 to 0.16 for cultivar IAC 144 (FIGURE 1).

Marana et al. (2008) mentioned DQI values higher than 0.2 as a reference for good seedling development. Between the environments, nursery 5 showed DQI of 0.33 and 0.26 for cultivar IAC 62 and IAC 144, respectively. Nursery 8 showed an index of 0.2 for cultivar IAC 144. Regardless of the evaluated cultivar, the remaining nurseries exhibited values below 0.2 for this variable (TABLE 4).

This index is a good indicator of seedling quality, as it considers the robustness and balance of biomass distribution in the seedling (FONSECA, 2000). Lemos et al. (2015) found a DQI of 0.24 at appropriate doses of citric acid and phosphorus used in the substrate for the production of coffee seedlings, which is below the value found in nursery 5 in the current experiment.

According to Gasparin (2012), seedlings with DQI below 0.2 have not yet reached the level of development to be marketed. This minimum desired value can be achieved through more appropriate management of the seedlings and of the genetic material used.

By analyzing the interaction between genotypes and environments (FIGURE 1) based on the $\mathrm{DQI}$ of the coffee seedlings, we observe that the cultivars responded differently to the management/ environment. In nursery 5, cultivar IAC 62 obtained a greater statistical difference in relation to IAC 144. In nurseries 1, 3, and 8, cultivar IAC 62 obtained a lower DQI than IAC 144 (TABLE 4).

The lower DQI obtained by the cultivars may be due not only to the management, but also the location and the sowing date (TABLE 3), since seeds can be subjected to colder temperatures that would delay the germination period and, therefore, seedling development.

In nurseries 1, 2, 3, and 7, in which sowing was performed earlier (TABLE 3), the seedlings had lower DQI at the time of evaluation. According to Meireles et al. (2007), in field conditions, germination occurs between 50 and 60 DAS, whereas in cold conditions it can occur in up to 120 days. 
Figure 1 - Genotype $\times$ environment interaction effect on Dickson quality index. IFSULDEMINAS Inconfidentes Campus. Inconfidentes/MG, 2018.

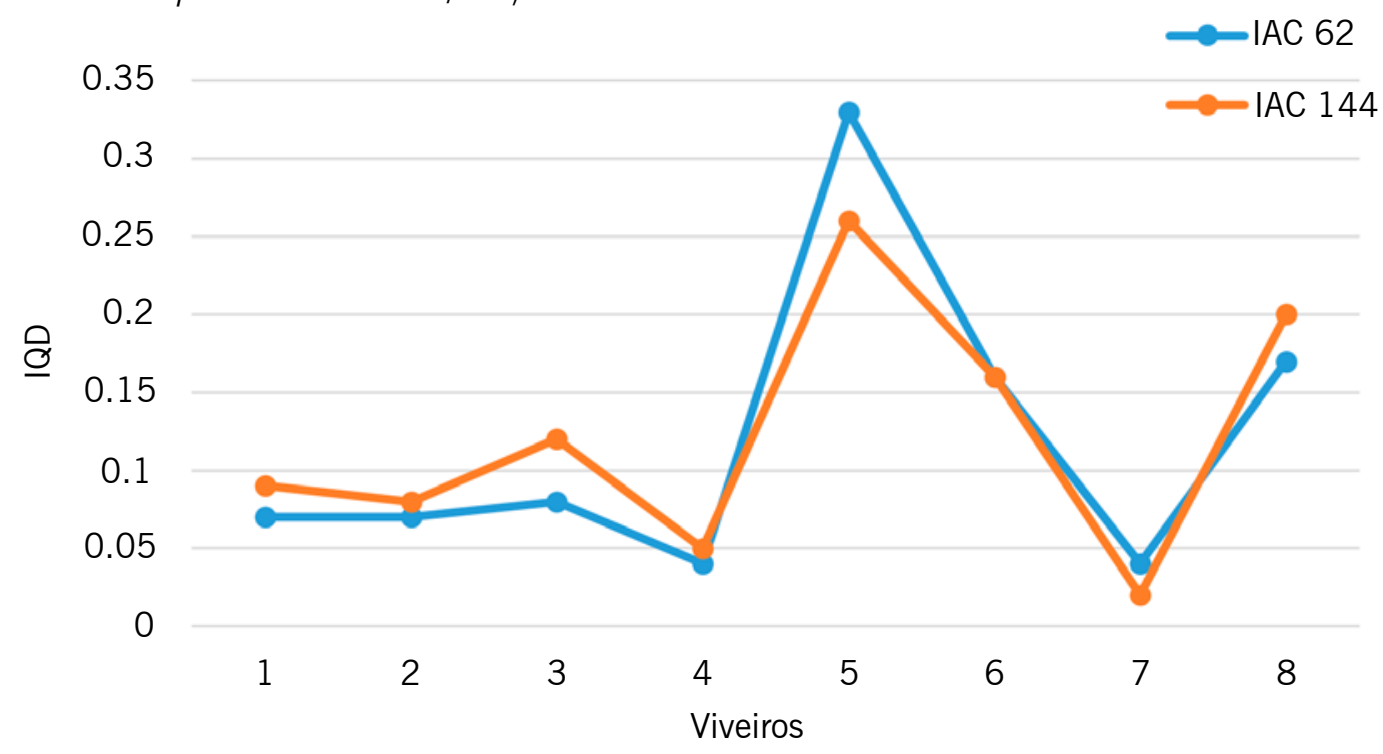

Source: Developed by the authors (2018).

It is inferred that the management adopted by nursery 5 (TABLE 2) was the most appropriate, providing better seedling quality in less time. The size of the container used by this nursery was the largest, which resulted in more substrate volume and a larger area for root growth, culminating in a greater TDM and a lower S: R.

Nursery 5 was also the only one to use $30 \%$ shade cloth, which may have contributed to the better growth of the coffee seedlings. Likewise, Tatagiba, Pezzopane and Reis (2010) found that shading levels between $22 \%$ and $50 \%$ provided greater vegetative growth in coffee seedlings when compared with seedlings grown in full sun and under $88 \%$ shading.

A noteworthy fact is that, except for nursery 4 , all nurseries used chicken manure or chicken litter in a minimum proportion of $20 \%$, which led to good results. This was especially true for nursery 5 , where $25 \%$ of chicken litter was used. The amounts of chicken litter used by nursery 5 corroborate the conclusions of Pereira, Lima and Melo Junior (2017), who stated that doses up to $25 \%$ favor the development of coffee seedlings.

Because nurseries 5 and 8 were the last to sow, the seedlings in those environments spent less time at lower temperatures, which allowed them to show better growth and quality parameters at 180 DAS.

At 180 DAS, the seedlings from nurseries $1,2,3,4,6,7$, and 8 still did not exhibit the quality required to go to the field. This results in a longer time for seedling formation, and, consequently, higher costs with inputs and labor and greater exposure to pests and diseases.

\section{Conclusion}

Only nursery 5 produced seedlings of adequate quality from both evaluated cultivars. Regardless of location and management, the other coffee-seedling nurseries still did not produce seedlings with satisfactory quality to be taken to the field. 


\section{Acknowledgments}

The authors thank the Federal Institute of Education, Science and Technology of Southern Minas Gerais (IFSULDEMINAS) for the financial support.

\section{Qualidade de mudas de Coffea arabica produzidas em diferentes viveiros do Sul de Minas}

\section{Resumo}

A obtenção de mudas de qualidade é de fundamental importância para o sucesso da implantação de uma lavoura cafeeira, podendo ser comprovada por meio da avaliação de parâmetros morfológicos e de qualidade das mudas. Este trabalho teve como objetivo avaliar a qualidade das mudas de cafeeiros produzidas em viveiros dos municípios de Inconfidentes, Ouro Fino e Jacutinga, região do Sul de Minas Gerais. $O$ experimento foi conduzido nos viveiros denominados 1, 2, 3, 4, 5, 6, 7 e 8, no período de 28 de maio de 2017 a 28 de fevereiro de 2018. 0 trabalho foi realizado em esquema fatorial $8 \times 2$, sendo 8 viveiros de mudas, 2 cultivares avaliadas, Catuaí nas linhagens IAC 62 e 144, com 3 repetições contendo 8 mudas cada. Foram avaliadas as seguintes características: área foliar (AF), massa seca total (MST), relação parte aérea raiz (RPAR), relação altura e diâmetro de coleto (RAD) e índice de qualidade de Dickson (IQD). Os dados foram submetidos à análise conjunta e após verificado diferenças significativas $(p<0,05)$ foi aplicado o teste de médias Scott Knott. 0 manejo nos viveiros influenciou o desenvolvimento das diferentes cultivares avaliadas. As mudas provenientes do viveiro 5 em ambas cultivares avaliadas e as mudas do viveiro 8 para a cultivar IAC 144 obtiveram IQD acima de 0,2, apresentando melhor qualidade. Apenas o viveiro 5 apresentou mudas, para as duas cultivares avaliadas, de qualidade adequada. Os demais viveiros de mudas de cafés, independentemente da localização, não apresentaram mudas com qualidade satisfatória para serem levadas a campo.

Palavras-chave: IQD. Catuaí. Viveirista. Análise conjunta.

\section{References}

ALVES, J. D.; GUIMARÃES, R. J. Sintomas de desordens fisiológicas em cafeeiro. In: GUIMARÃES, R. J., MENDES, A. N. G., BALIZA, D. P. (Ed.). Semiologia do cafeeiro: sintomas de desordens nutricionais, fitossanitárias e fisiológicas. Lavras-MG: UFLA, 2010. 215p.

BARROS, R. S.; MAESTRI, M.; VIEIRA, M.; BRAGA FILHO, L. J.; MAESTRI, M.; VIEIRA, L.; BRAGA, L. W. Determinação de área de folhas do café (Coffea arabica L. cv. Bourbon Amarelo). Revista Ceres, Viçosa-MG, v. 20, n. 107, p. 44-52, 1973.

CARVAlHO, A. M.; GUIMARÃES, R. J.; MOURA, C. A.; MENDES, A. N. G.; CARVALHO, G. R. Recuperação de mudas de cafeeiro em tubetes através de podas. Coffee Science, Lavras-MG, v. 2, n. 1, p. 79-86, jan./jun. 2007. Available at: http://www.coffeescience.ufla.br/index.php/Coffeescience/article/ view/42/37. Access on: 24 jun. 2020. 
CARVALHO, G. R.; GUIMARÃES, P. T. G.; NOGUEIRA, A. M. Normas e padrões para a comercialização de sementes e mudas de cafeeiros em Minas Gerais. Informe Agropecuário, Belo Horizonte, v. 29, n. 247, p. 24-30, 2008.

CLIMATE-DATA.ORG. Clima: Inconfidentes. Available at: https://pt.climate-data.org/america-do-sul/ brasil/minas-gerais/inconfidentes-176515/. Access on: 2 set. 2018.

CONAB. Companhia Nacional de Abastecimento. Acompanhamento da Safra Brasileira de Café. Volume 4 - Safra 2017, n.3. Terceiro levantamento. Brasília, p. 1-107. 2017. Available at: https://www.conab.gov.br/index.php/info-agro/safras/cafe. Access on: 2 set. 2018.

DARDENGO, M. C. J. D.; SOUSA, E. F.; REIS, E. F.; GRAVINA, G.A. Crescimento e qualidade de mudas de café conilon produzidas em diferentes recipientes e níveis de sombreamento. Coffee Science, Lavras-MG, v. 8, n. 4, p. 500-509, 2013. Available at: http://coffeescience.ufla.br/index. php/Coffeescience/article/view/512/pdf_68. Access on: 24 jun. 2020.

DICKSON, A.; LEAF, A. L.; HOSNER, J. F. Quality appraisal of white spruce and white pine seedling stock in nurseries. Forest Chronicle, v. 36, p. 10-13, 1960. Available at: https://pubs.cif-ifc.org/doi/ pdf/10.5558/tfc36010-1. Access on: 2 set. 2018.

FERREIRA, D. F. Sisvar 5.1 - Análises estatísticas por meio do Sisvar para Windows. Lavras: Universidade Federal de Lavras, 2011. p.255-258.

FONSECA, E. P. Padrão de qualidade de mudas de Trema micrantha (L.) Blume., Cedrela fissilis Vell. e Aspidosperma polyneuron Muil Arg. produzidas sob diferentes períodos de sombreamento. Jaboticabal, UEP, 2000. 113p. Tese (Doutorado em Agronomia) - Universidade Estadual Paulista. Available at: https://repositorio.unesp.br/bitstream/handle/1 1449/27716/S0100-67622002000400015. pdf? sequence $=1$ \&isAllowed=y. Access on: 24 jun. 2020.

FONTENO, W. C.; BILDERBACK, T. E. Impacto of hydrogel on physical properties of coarse-structured horticultural substrates. Journal American Society For Horticultural Science, v. 118, n. 2, 1993. Available at: https://journals.ashs.org/jashs/view/journals/jashs/118/2/article-p217.xml. Access on: 24 jun. 2020.

GASPARIN, E. Armazenamento de sementes e produção de mudas de Parapiptadenia rigida (Benth.) Brenan. Santa Maria-SC: UFSA, 2012, 146p. Dissertação (Mestrado em Engenharia Florestal) Universidade Federal de Santa Maria. Available at: https://repositorio.ufsm.br/bitstream/handle/1/8691/ GASPARIN\%2c\%20EZEQUIEL.pdf?sequence=1\&isAllowed=y. Access on: 24 jun. 2020.

GOMES, J. M.; PAIVA, H. N. Viveiros florestais: Propagação sexuada. Viçosa, MG: UFV, 2004.

KAINUMA, R. H.; MIGLIORANZA, E.; FONSECA, E. P.; MONTANARI, E.; FRANCO, E. Qualidade de mudas Coffea arabica desenvolvidas em diferentes substratos e doses de adubo de liberação lenta. In: II Simpósio de Pesquisa dos cafés do Brasil. 2002, Porto Seguro - BA. Resumos. p. 1865-1872. Available at: http://www.sapc.embrapa.br/arquivos/consorcio/spcb_anais/simposio2/manejo40.pdf. Access on: 24 jun. 2020.

KÖPPEN, W.; GEIGER, R. Die klimate der Erde. Wall-map $150 \mathrm{~cm}$ x $200 \mathrm{~cm}$, Gotha: Verlag Justus Perthes, 1928. 
LEMOS, V. T.; FRANÇA, A. C.; SILVA, E. B.; MARINHO, R. L. S.; FRANCO, M. H. R.; AVELAR, M.; FREITAS, A. F.; REIS, L. A. C; CORREA, J. M.; CARVALHO, G. R. Ácido cítrico e fósforo no desenvolvimento e estado nutricional de mudas de café. Coffee Science, v. 10, n. 3, p. 298-308, 2015. Available at: http://www.coffeescience.ufla.br/index.php/Coffeescience/article/view/858/pdf_183. Access on: 24 jun. 2020.

MARANA, J. P.; MIGLIORANZA, E.; FONSECA, E. de P.; KAINUMA, R. H. Índices de qualidade e crescimento de mudas de café produzidas em tubetes. Ciência Rural, Santa Maria, v. 38, n. 1, p. 39-45, 2008. Available at: https://www.scielo.br/pdf/cr/v38n1/a07v38n1.pdf. Access on: 24 jun. 2020.

MEIRELES, R. C.; ARAÚJO, E. F.; REIS, M. S.; SEDIYAMA, C. S.; SAKIYAMA, N. S.; REIS, L. S. SECAFÉ: metodologia para acelerar a germinação das sementes de café. Revista Brasileira de Sementes, v. 29, n. 3, p. 90-96, 2007. Available at: https://www.scielo.br/pdf/rbs/v29n3/a12v29n3.pdf. Access on: 24 jun. 2020.

MENEGHELLI, L. A. M.; MONACO, P. A. V. L.; HADDADE, I. R.; MENEGHELLI, C. M.; KRAUSE, M. R.; VIEIRA, G. H. S. Produção de mudas de café arábica em substrato composto de resíduo da secagem dos grãos. Coffee Science, v. 12, n. 3, p. 381-388, 2017. Available at: http://www.coffeescience. ufla.br/index.php/Coffeescience/article/view/1312/pdf_1312. Access on: 24 jun. 2020.

MORAES, G. A. B. K.; CHAVES, A. R. M.; MARTINS, S. C. V.; BARROS, R. S.; DAMATTA, F. M. Why is it better to produce coffee seedlings in full sunlight than in the shade? A morphophysiological approach. Photosynthetica (Praha), v. 48, n. 2, p. 199-207, 2010. Available at: http://dx.doi.org/10.1007/ s11099-010-0025-4. Access on: 24 jun. 2020.

MUNGUABE, J. F. Qualidade morfológica de mudas clonais de eucalipto na fase de expedição em viveiros comerciais. 2012. Dissertação (Mestrado em Ciências Florestais) - Universidade Federal de Lavras, Lavras, 2012. 73p. Available at: http://www.bibliotecaflorestal.ufv.br/bitstream/handle/123456789/13829/ Dissertacao_Joao\%20Faustino\%20Munguambe.pdf?sequence=1\#: :text=Foram\%20avaliadas\%20 mudas $\% 20$ clonais $\% 20$ de,calculados $\% 20$ os $\% 20$ seguintes $\% 20 \%$ C3\%ADndices $\% 3$ A 20 rela\%C3\%A7\%C3\%A3o. Access on: 24 jun. 2020.

PEREIRA, I. S.; LIMA, K. C. C.; MELO JUNIOR, H. B. Substratos orgânicos na produção de mudas de cafeeiro em tubetes. Revista de Agricultura Neotropical, v. 4, n. 2, p. 17-26, 2017. Available at: https://periodicosonline.uems.br/index.php/agrineo/article/view/1254/1369. Access on: 24 jun. 2020.

SCOTT, A.; KNOTT, M. Cluster-analysis method for grouping means in analysis of variance. Biometrics, Washington D.C., v. 30, n. 3, p. 507-512, 1974. Available at: https://www.ime.usp.br/ abe/lista/ pdfXz71qDkDx1.pdf. Access on: 24 jun. 2020.

TATAGIBA, S. D.; PEZZOPANE, J. E. M.; REIS, E. F. Crescimento vegetativo de mudas de café arábica (Coffea arabica L.) submetidas a diferentes níveis de sombreamento. Coffee Science, v. 5, n. 3, p. 251-261, 2010. Available at: http://www.coffeescience.ufla.br/index.php/Coffeescience/article/ view/131/pdf. Access on: 24 jun. 2020.

Received: December 2, 2019

Accepted: June 24, 2020 